\title{
How should conservation be professionalized?
}

\author{
Michael R. Appleton, James R. Barborak, Jennifer C. Daltir \\ Barney Long, Mark O'Connell, Nisha R. Onen, Rohit Singh \\ Emily Sparkes, Eleanor J. Sterling and Lina M. Valencia
}

\begin{abstract}
Meeting the complex demands of conservation requires a multi-skilled workforce operating in a sector that is respected and supported. Although professionalization of conservation is widely seen as desirable, there is no consistent understanding of what that entails. Here, we review whether and how eight elements of professionalization observed in other sectors are applicable to conservation: (1) a defined and respected occupation; (2) official recognition; (3) knowledge, learning, competences and standards; (4) paid employment; (5) codes of conduct and ethics; (6) individual commitment; (7) organizational capacity; and (8) professional associations. Despite significant achievements in many of these areas, overall progress is patchy, and conventional concepts of professionalization are not always a good fit for conservation. Reasons for this include the multidisciplinary nature of conservation work, the disproportionate influence of elite groups on the development and direction of the profession, and under-representation of field practitioners and of Indigenous peoples and local communities with professional-equivalent skills. We propose a more inclusive approach to professionalization that reflects the full range of practitioners in the sector and the need for increased recognition in countries and regions of high biodiversity. We offer a new definition that characterizes conservation professionals as practitioners who act as essential links between conservation action and conservation knowledge
\end{abstract}

Michael R. Appleton (Corresponding author, (1) orcid.org/0000-0003-1669162X, mappleton@rewild.org), JeNNIFER C. DALTRY* (10 orcid.org/0000-00030364-9465), BarNey Long (10 orcid.org/0000-0002-9747-6042) and Lina M. VAlencia (10 orcid.org/0000-0001-5513-563X) Re:wild, P.O. Box 129, Austin, Texas 78767, USA

JAMEs R. BARBoraK (ㄷ) orcid.org/0000-0003-1235-8707) Colorado State University, Fort Collins, USA

Mark O'Connell (®D orcid.org/0000-0003-3402-8880) and Emily Sparkes University of Gloucestershire, Cheltenham, UK

Nisha R. OWen (10) orcid.org/0000-0001-5094-8332) On the EDGE Conservation, London, UK

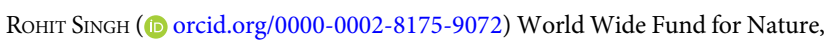
Singapore

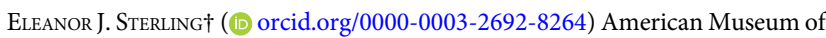
Natural History, New York, USA

${ }^{*}$ Also at: Fauna \& Flora International, Cambridge, UK

$\dagger$ Also at: Hawai'i Institute of Marine Biology, Honolulu, USA

Received 1 November 2020. Revision requested 21 January 2021.

Accepted 12 April 2021. First published online 1 December 2021. and policy, and provide seven recommendations for building a more effective, inclusive and representative profession.

Keywords Association, capacity, competence, conservation, occupation, practitioner, profession, standards

\section{Introduction}

fforts to reduce biodiversity loss, implement international conventions and meet agreed global conservation targets will require increasing numbers of knowledgeable, skilled, experienced and committed people. Modern conservation is a multidisciplinary occupation, requiring workers who can succeed in complex and shifting work contexts, spanning (inter alia) life, earth and social sciences, agriculture, fisheries, forestry, tourism, recreation, economics, law, criminology, communication, education and human health, and requiring entrepreneurial, leadership and management skills.

To meet this need, there have been calls for conservation to be established as a profession 'of equal importance to healthcare and the law' (Dudley \& Stolton, 2020, p. 171). Mieg (2009, p. 94) defined professions as 'relatively autonomous occupational groups that claim jurisdiction over a certain class of tasks' but there is currently no common understanding of what professionalization means in the context of conservation, what being a conservation professional involves, or the risks and benefits of professionalization.

\section{Professionalization in the context of conservation}

We searched, using search engines Google (Google, Mountain View, USA), Ecosia (Ecosia GmbH, Berlin, Germany) and ResearchGate (ResearchGate GmbH, Berlin, Germany), for generic definitions of the terms 'profession', 'professional' and 'professionalization' and for peer-reviewed articles and grey literature using these terms in the field of conservation. From these, we identified eight main attributes of professionalization through an iterative process, including discussions with peers, conference discussions, and a workshop on professionalization in conservation (BfN, 2017). The following sections identify how each attribute could potentially benefit the conservation sector, review progress to date and highlight aspects where generic concepts of 
professionalization do not readily align with the needs and directions of the emerging conservation profession.

\section{(1) A defined and respected occupation}

Established professions (e.g. doctor, lawyer) are generally based around a clearly defined sphere of knowledge and expertise (Saks, 2012). Interpretations of the term 'conservation professional', however, vary widely. Jeanson et al. (2020) provided a non-exhaustive list of conservation professionals comprising the scientific community, policymakers and governing bodies, youth educators, resource managers, resource stakeholders, funding agencies and Indigenous knowledge holders. Papworth et al. (2019, p. 405) asked 'Do you consider yourself to work in biodiversity conservation?' to identify professionals, whereas Lucas et al. (2017) stipulated possession of a master's degree. Blanchard et al. (2018) identified conservation professionals as those working for conservation NGOs, distinct from conservation science researchers and social scientists. Francis \& Goodman (2010) distinguished three main groups in conservation: researchers (mainly academics), professionals in governmental agencies (focusing mainly on decisionmaking), and those in NGOs focusing mainly on conservation practice.

Respect and trust are attributes widely associated with professionalism (Evetts, 2006), but the respect called for by Dudley \& Stolton (2020) will be difficult to achieve without a more consistent understanding of what a conservation professional is, and will remain a challenge so long as conservationists are primarily regarded as activists (Klas et al., 2018), sentimental wildlife lovers or even economic terrorists (Handy, 2019). According to Paterson (2006, p. 149) 'The concept of the wildlife conservationist is that of a resource manager whose job is to manage natural resources for the benefit of people, but who is fighting an ongoing battle to prove the value of this work.'

\section{(2) Official recognition}

Well-established professions are normally officially recognized through inclusion in national registers of occupations and/or through legal restrictions on practising the profession to those with required qualifications and certification, often defined by recognized professional associations. This helps to maintain common, consistent high standards and signals and encourages trust. Conservation, however, is not widely recognized as a distinct profession, or even as an occupation. The International Labour Office's (2008) standard classification of occupations includes Environmental Protection Professionals as a subcategory of Life Science Professions but does not mention conservation. Although some countries, for example Canada, recognize specific conservation occupations, many, such as India, classify conservation work alongside agriculture, forestry, fisheries and hunting.

\section{(3) Knowledge, learning, competences and standards}

Brock et al. (2014) characterize a profession as a knowledgeintensive occupation, but being a professional should also involve the application of knowledge (Abbott, 1988). Definitions of professions emphasize both the need for specialized education and training and for common standards of competence (e.g. Cambridge University Press, 2020; Corporate Finance Institute, 2020).

The volume of conservation knowledge products is continually increasing in the form of articles, reports, guidelines, books and websites, but much of this material is available only in English. Furthermore, expensive and/or unreliable internet connections may limit access in regions where many conservationists work. Scientific studies and new ideas are still mainly published in peer-reviewed journals that are often difficult to locate, in some cases expensive to access, and written using language and styles not aimed at practitioners, few of whom consult journals (Gossa et al., 2015; Giehl et al., 2017; but see Fabian et al., 2019). These barriers are now being addressed by collating and presenting results and experiences in more accessible, diverse and engaging formats (Walsh et al., 2015; O'Connell \& White, 2017; Fabian et al., 2019; Conservation Evidence, 2021).

Indigenous and local knowledge is increasingly recognized as being as valuable to conservation as expert professional knowledge (Adams \& Sandbrook, 2013). But formalizing Indigenous and local knowledge systems into frameworks of professional management can lead to erosion of endemic, place-based Indigenous and local knowledge and management practices (Nadasdy, 2003).

Availability of training and learning has also expanded. There has been a proliferation of high-level courses on topics such as conservation leadership (Bruyere et al., 2020), and some academic institutions are successfully blending academic and professional/vocational conservation training; e.g. the African Leadership University, the Wildlife Institute of India, CATIE in Costa Rica and Colorado State University in the USA. However, the majority of such programmes are still based in Europe, North America and Australasia, are in English and are unaffordable for many students from tropical countries without scholarship support (Bonine et al., 2003).

Local or regional training colleges may be more accessible in many countries, and may be more experienced than universities in providing appropriate professional training. In Africa, for example, the Southern Africa Wildlife College (South Africa), the College of African Wildlife Management, Mweka (Tanzania) and the Ecole de Faune de Garoua (Cameroon) provide vocational 
programmes tailored to the needs of national and regional conservation practitioners. Some protected area agencies (e.g. in Kenya and Bhutan) have developed their own internal training and professional development programmes. Distance learning is also extending access to learning and knowledge: since launch in 2015 up until May 2020, the free certified online training programmes offered by the IUCN Programme on African Protected Areas and Conservation have attracted over 47,000 participants from over 120 countries (IUCN PAPACO, 2021).

Unlike established professions, however, the conservation sector lacks common competences and standards. This means that jobseekers with science-based academic qualifications are often inadequately prepared to enter the sector (Muir \& Schwartz, 2009), also creating an impression that only highly qualified scientists can be conservation professionals, and fuelling the demand for ever higher qualifications for the same job ('qualification inflation'; Fuller \& Raman, 2017, p. 4). Requirements for entrance exams or academic credentials may discriminate against Indigenous people and other highly competent individuals who have not benefited from conventional education.

The need to bridge the gap between mainly academic knowledge and conservation practice has been regularly highlighted (e.g. Whitten et al., 2001; Gossa et al., 2015) and is an issue likely to persist without common frameworks of professional competence and associated certification. Work is underway to address this, however. A competence register for protected area practitioners (Appleton, 2016) is increasingly being used to guide development of learning programmes, job descriptions and organizational structures, and similar register has been developed for threatened species recovery practitioners (Maggs et al., 2021). The WIO-COMPAS programme has successfully pioneered the linking of competences, learning programmes and performance-based certification for marine protected area professional practitioners in the West Indian Ocean (WIOMSA, 2020). Beyond structured training and learning, some large conservation NGOs have developed formal continuing professional development programmes, and new professional networks, such as the Conservation Coaches Network, WildHub and CoalitionWILD, support professional development of conservationists through knowledge sharing, mentoring and co-development of new approaches and methods.

\section{(4) Paid employment}

A widespread definition of profession is that professionals are paid for their work (e.g. Cambridge University Press, 2020). In conservation, however, paid employment is a poor indicator of professional status, and the antonyms of professional (e.g. unprofessional, amateur) are potentially derogatory. Numerous volunteers commit their time and expertise freely and play substantive roles in most areas of conservation. For aspiring professionals seeking entry to the sector, volunteer or intern positions may be the only options (Hance, 2017) and many skilled conservationists continue to work unpaid between periods of short-term employment, although the ethics and utility of unpaid conservation work are increasingly being questioned (Fournier \& Bond, 2015). Many Indigenous people and local community members possess expertise analogous to that of acknowledged conservation professionals but are not specifically employed as conservationists. The term 'paraprofessional' has been used to describe Indigenous and local conservation co-workers (e.g. Painter \& Kretser, 2012), but we suggest this term should be avoided because it could be seen as denigrating Indigenous and local knowledge and skills.

\section{(5) Codes of conduct and ethics}

A strong case for a common code for conservation professionals was made by Bennett et al. (2017, p. 412): 'Many other professions, including doctors, lawyers, engineers, accountants and teachers, have codes of conduct to establish a firm foundation for practice. However, there is no similar social standard or mechanism to guide the actions of individual conservation practitioners, organizations or governments, or to hold them accountable'. Codes exist for some aspects of conservation work, for example, research and field work in protected areas (Hockings et al., 2013), the work of rangers (International Ranger Federation, 2021) and ensuring respect for the cultural and intellectual heritage of Indigenous and local communities (the Tkarihwaié:ri Code adopted at the 1oth Conference of Parties of the Convention on Biological Diversity; CBD, 2010). Most international conservation NGOs have internal codes of conduct (e.g. WWF, 2009) as do professional associations in conservation-related fields such as the Chartered Institute of Ecology and Environmental Management (CIEEM, 2019). Some peer-reviewed journals in the field of conservation have established ethical standards/codes of conduct for published research (e.g. Adams et al., 2001). As the conduct of conservation workers comes under increasing scrutiny (e.g. Warren \& Baker, 2019), the need for a common code is becoming more apparent, but codes alone are no guarantee against malpractice without mechanisms for monitoring, reporting on and responding to violations (Webley \& Werner, 2008).

\section{(6) Individual commitment}

Being professional implies a high degree of personal integrity and commitment, and conservationists are often expected to demonstrate exceptional dedication in a career 
that is for many 'a vocation as well as a profession' (E.J. Milner-Gulland, quoted in Hance, 2017). But such commitment may lead employers and the public to assume that conservationists require lower remuneration than corporate employees (Fournier \& Bond, 2015), favouring those able to afford the necessary personal and financial sacrifices (Hance, 2017). This can potentially undermine professionalization; staff who are overworked, poorly paid, stressed and badly led are more likely to make mistakes, behave unprofessionally or even endure post-traumatic stress disorder (Belecky et al., 2019). Although conservation is likely to remain a demanding occupation requiring particular commitment, the concept of a professional conservationist should not exclude those who are competent, committed and hardworking but who need to balance other life needs with the demands of work, or who are unable to engage in certain aspects of conservation work. This issue also affects public perceptions of conservationists as professionals. Strong commitment does not alone provide a mandate for conservation action and may even be perceived by some as indicating an ulterior financial motivation for doing the work (Holmes, 2015).

\section{(7) Organizational capacity}

Effective professional employees need effective, professional organizations. Progress is being made on building professionalism of conservation NGOs, supported by initiatives such as Capacity for Conservation (2021) and organizations such as Maliasili (2020) and Well-Grounded (2021). Building the capacity of government conservation agencies is often more challenging for multiple reasons, including: inflexible systems and processes; resource shortages; inadequate working and employment conditions (Belecky et al., 2019); issues of transparency, equity, inclusion and diversity that limit recruitment, retention and promotion opportunities (Smith et al., 2015); limited access to training and professional development (Appleton et al., 2017); high personnel turnover, often linked to political changes or funding fluctuations; and discrimination against women, including gender-based violence (Castañeda Camey et al., 2020).

Failure to address organizational deficiencies has direct impacts on professionalizing conservation. It can lead to demotivation, lowering of standards, weak performance, public distrust, corruption (UNODC, 2019) and the loss from the sector of talented professionals frustrated at the lack of progress and opportunities. A workshop on this topic (BfN, 2017) identified four main requirements for government conservation agencies to be more effective: structures and systems that allow them to manage, collaborate and adapt to change effectively; proactive, confident and collaborative individuals who deliver effectively and inspire others; engagement in diverse and productive partnerships; and responsiveness to the needs of a society that understands and supports conservation goals.

Adoption of certified performance standards has the potential to build capacity and improve overall professionalism in conservation organizations. Such standards are increasingly being adopted for protected and conserved areas through the IUCN Green List of Protected and Conserved Areas (IUCN \& WCPA, 2017), the Conservation Assured Tiger Standards (Conservation Assured, 2018), and the ISO 9000 and 14000 standards for management (Cabayan, 2019; Dolomiti Bellunesi National Park, 2020).

\section{(8) Professional associations}

Established professions generally have formal members' associations whose main functions are summarized by Hurd \& Lakhani (2008, p. 5): 'Professional associations essentially establish identity and dignity for the profession by setting minimum educational requirements, national certification standards and a code of ethics that outlines the expectations of professional behaviour for members of that profession ... Associations also provide mechanisms for members to advance knowledge, disseminate information and network with their peers.' Although some existing professional associations (e.g. the UK Chartered Institute of Ecology and Environmental Management and the US-based Society for Ecological Restoration) meet these criteria and encourage global membership, no global association exists specifically for conservation professionals. Several bodies fulfil some roles of professional associations but are not constituted as such. For example, the International Ranger Federation is actively promoting professionalization of rangers (Singh et al., 2021); members of the Society for Conservation Biology have access to professional development networks and opportunities; and the six IUCN Commissions have expert memberships, a code of conduct and a commitment to developing and promoting professional good practice. In the early 1990s the IUCN Commission on National Parks and Protected Areas (the precursor to the World Commission on Protected Areas) considered creating an international society of protected area managers and professionals within the Commission (Munro, 1992), but this was never established. Conservation workers in some countries are represented by labour unions, which advocate for improved employment and working conditions.

Professionalization of conservation could still continue in an ad hoc way, but without a widely recognized body or set of related bodies to establish and uphold common standards and promote the profession in a consistent way, progress is likely to remain fragmented and favour only certain groups. A formal professional body or network could potentially (1) build a valued identity for the profession; 
(2) establish a global framework of standards for professional practice; (3) research sectoral needs, trends and policies, and lobby for change; (4) promote diversity, equity, inclusion and justice in the profession; (5) be a hub for sharing knowledge, experience and good practice; and (5) represent all conservation professionals.

\section{Discussion}

All eight aspects of professionalization considered here offer potential benefits for conservation, but there may also be risks. Among conservation NGOs, for example, Larsen (2018) distinguished The Good (small, idealistic, commitment-driven); The Ugly (professionalized, managerial and internationally financed institutions that increasingly rely on a capitalistic expansion of activities, public finance entanglements and flawed corporate partnership projects) and the Dirty Harrys (pragmatic conservation operators in a world of money). The latter reflect a perceived shift towards neoliberalism (Humble, 2019), defined by Lang (2013, p. 63) as 'the processes through which social movements professionalize, institutionalize and bureaucratize in vertically structured, policy-outcome-oriented organizations that focus on generating issue-specific and, to some degree, marketable expert knowledge or services'. This emergence of corporate conservation, exemplified by the growth of the so-called BINGOs (big international NGOs), has attracted extensive criticism, including accusations of colonialism (Mbaria \& Ogada, 2017), undue influence by business donors (Hance, 2016), lack of concern for Indigenous issues and human rights (Tauli-Corpuz et al., 2020), and overprofessionalization (Banks et al., 2015).

Professionalization will also perpetuate exclusivity if it does not address exclusion of, and discrimination against, professionals based on race (Mbaria \& Ogada, 2017; Gantheru, 2020), geographical origin or gender (Jones \& Solomon, 2019). Conservationists whose career paths and education do not conform to professional models could also become excluded. The emerging conservation profession needs to rigorously examine and, where necessary, reshape prevailing attitudes and conservation norms that perpetuate discrimination, exclusion and abuse of rights. Establishing formal structures that attempt to centralize the profession, restrict entry to certain groups and individuals, favour certain viewpoints and charge high membership fees could hinder professionalization. Exclusivity may also undermine trust among the wider public. In the context of heritage conservation, Lowenthal (1999, p. 7) warned that 'professionalisation ... has served more to increase public distrust rather than trust: with it goes resentment that heritage concerns are dominated by elites and special interest groups, and suspicions of self-interest undermine appreciation of heritage as a public commodity'.
Overall, the conservation sector does not readily fit the model of a traditional profession. It is highly multidisciplinary, blending elements of many occupations to the extent that a single professional identity is difficult to define. Whereas most traditional professions are built around selling or providing a defined set of services to individuals or organizations, conservation seeks to deliver a wide suite of services to society as a whole, services that are often not easily defined or readily marketable and that may not be mandated. Most professions tend to concentrate knowledge, expertise and, in some cases, the right to practise within exclusive groups, whereas the global and interconnected nature of conservation requires an expansion and diversification of its practitioners.

Conservation therefore needs to develop its own distinctive professional profile. The starting point is clarifying who is a conservation professional. We see the sector comprising three broad and significantly overlapping groups:

Facilitators This group mainly comprises policy makers, conservation staff of government agencies, international NGOs and donors, and many in the academic community. Largely English-speaking or multilingual, this group is based mainly in more developed and middle-to-upper income countries and urban areas. Because of the seniority, capacity, connections and resources of its members, this group has a major influence on shaping and directing conservation research, policy and practice, and consequently on defining the conservation profession. Considered by Holmes (2011, p. 2) as a 'transnational conservation elite', this group has been associated with the advance of so-called neoliberal conservation. Some influential members of this group are not directly engaged in conservation practice and, although this group provides much of the raw material that drives and evaluates applied conservation activities through policy, publications and media, they are often considered by many practitioners to be out of touch with the realities and needs of conservation practice.

Conservation sector practitioners With a focus on applying plans and policies, this group has much more direct impact on day-to-day conservation practice than the facilitators. Practitioners work in public sector bodies responsible for environmental protection, protected areas and natural resource management, and as staff of private protected areas, small NGOs and local offices of larger NGOs. Many do not have English as a first language, although increasing numbers have benefited from training abroad (mainly in English). They include large numbers of young professionals and volunteers, albeit often with significant knowledge and experience. We consider this practitioner group constitutes the under-represented majority of mainstream conservation professionals, with disproportionately limited 
TABLE 1 Seven general recommendations for advancing professionalization of conservation, with the core issues identified for each recommendation.

Recommendations (1-7)

\& core issues

Details

(1) Secure wider recognition of the conservation profession \& sector

Conservation professionals should be understood \& respected in a similar way to medical professionals, working towards the well-being of the planet \& its life support systems.
Include conservation work in official national occupational registers, to drive improvements in employment/working conditions, increase influence \& trigger state support for training \& education Promote studies \& narratives that redefine conservation as a distinctive, inclusive, diverse, complex occupation that delivers important benefits to society

\section{(2) Increase the availability \& accessibility of knowledge}

All conservation professionals need to be able to benefit from \& contribute to the growing body of knowledge on conservation practice.
Extend initiatives that widen access to research, codify good practice, develop \& disseminate case studies, \& make better use of technological advances in education \& knowledge exchange Enable development of knowledge products by practitioners from different geographies \& cultures $\&$ in different languages

Improve awareness \& understanding of the value of Indigenous \& local knowledge in professional practice

\section{(3) Improve the quality, relevance \& availability of training \& learning}

Training \& learning need to be more accessible \& inclusive \& be driven by the conservation sector.
Develop further competence frameworks for specialist aspects of conservation practice Develop national standards \& systems of certification \& recognition of skills (including as an alternative to formal education requirements for employment)

Develop a system for sectoral endorsement/accreditation of courses aligned with global standards Widen involvement of technical/vocational colleges \& institutes (e.g. for wildlife management, forestry, fisheries, agriculture \& tourism) in delivering professional training Further develop certified online \& blended learning programmes Improve systems for continuing professional development in conservation organizations Extend communities of practice, mentoring networks \& other learning routes for busy professionals Evaluate the impact of capacity development \& professionalization on conservation efforts

\section{(4) Establish an ethical framework for all conservation professionals}

This would help define \& promote the profession, providing a benchmark for conservationists to aspire to \& against which they can be held accountable.
Develop a code of ethics \& conduct, \& supporting guidance for all conservation professionals Provide guidance on \& promote adoption of safeguarding policies \& procedures

\section{(5) Build wider \& more inclusive networks of professionals}

The professional conservation community needs to proactively include a much wider group of practitioners in all aspects of conservation work \& sectoral leadership.
Extend professional networks \& support new networks that are accessible to the diversity of conservation professionals

Re-evaluate approaches \& attitudes that define the profession \& drive exclusionary \& discriminatory practices (Sandbrook et al., 2019)

Consult excluded \& marginalized groups to learn how they can best participate more actively Expect direct involvement in conservation practice by academic institutions pursuing leadership roles in the sector, leading to: improved understanding of the realities of conservation practice; more interdisciplinary \& action-driven learning programmes; more needs-driven identification of research priorities; improved capacity to provide practical guidance, training \& recommendations (Taff et al., 2015)

\section{(6) Improve organizational performance, employment \& working conditions}

Conservation professionals require effective, supportive \& responsive organizations.
Conduct surveys on employment \& working conditions in the conservation sector

Develop a charter for employers on fair treatment \& working conditions for all conservation professionals

Promote organizational policies \& procedures to address discrimination, abuse, overwork, stress \& unreasonable expectations

Strengthen elements relating to organizational performance in the IUCN Green List of Protected \& Conserved Areas, Conservation Assured Tiger Standards \& other performance measures 
TABLe 1 (Cont.)

Recommendations (1-7)

\& core issues Details

(7) Explore options for forming a professional body or network to advance professionalization

Professionalization will be aided by a coherent \& coordinated approach beyond the scope of existing bodies.
Three main options have been identified: establish a new single global professional association; extend the remit of an established association or associations to include conservation professionals as defined here; create a hub for a network of associations that would establish/support establishment of common standards \& codes, incorporate existing networks \& structures, \& encourage establishment of diverse professional associations (thematic \& geographical) influence on the profession's development and direction. Working in organizations that are usually understaffed and under-resourced, many are multifunctional generalists as well as subject specialists, with limited access to learning opportunities or to the networks and events in which the profession is shaped. Public sector workers in particular may be restricted from expressing strong personal or professional opinions publicly.

Community and Indigenous practitioners We acknowledge that the concept and language of professionalism as used in this paper may not reflect the traditional cultures and viewpoints of many conservationists around the world. Nonetheless, we consider people who use Indigenous and local knowledge, and skilful leadership and governance to guide natural resource stewardship and conservation, to be as much professionals as university-trained conservation managers. For many in this group, conservation is integral to their lives rather than being a job, and they may work within different conceptualizations of the purpose and practice of conservation. This group is securing increased recognition but still has limited influence on the development and direction of conservation practice and the profession in general. Some members of this group may be uncomfortable with being labelled as professionals and may even find themselves in conflict with the other two groups.

For the conservation sector to be better respected and recognized, and for professionalization to be a positive process, it needs to be a broad and inclusive profession that reflects the full diversity of its practitioners and the complexity of its work. We consider that the future expansion of the sector will and should be close to areas of high conservation value and that therefore the direction of this emerging profession should be shaped and led more by practitioners in the second and third groups than it is at present.

Professional conservation practice should be rooted in good science from multiple disciplines but also requires significant social, cultural and political skills, alongside generic skills such as leadership, communication and entrepreneurship. It should blend rational thinking with creation, innovation and sensitivity to develop and apply solutions that reduce threats and achieve conservation goals in the context of constant ecological, social, political and economic change and uncertainty. This multifunctional role is best understood in the context of trans-professionalism, involving 'deliberate exchange of knowledge, skills and expertise that transcends traditional disciplinary boundaries' (Chiocchio \& Richer, 2015, p. 163). It should also be viewed as a shift from traditional, closed models of knowledge production to more decentralized, reflective and transdisciplinary approaches (Reihlen \& Mone, 2012) that are also transcultural. Alongside adopting the core elements of a profession (i.e. codes, standards, professional development), we should work towards the first of Mieg's (2008, p. 50) two main routes for professionalization: an integrated value-and-work based professionalisation based on individual expertise and shared values among diverse experts from different occupational groups, some without university education', rather than his second, 'academia-based professionalisation'. We should share Kiik's (2019, p. 392) vision of 'Conservationland': 'a transnational social world of nature conservation, including both expat and local-national professionals'.

In short, conservation professionals should not remain on either side of the bridge between theory and practice, or between traditional and scientific approaches, they should be the bridge itself, spanning the facilitating framework and applied conservation practice. Their work should involve building knowledge and expertise of all types and facilitating diagnosis, prescription, monitoring and communication (Abbott, 1988). Conservation professionals may work within and across the cultural frameworks of both mainstream and Indigenous and community conservation, according to the context and the rights and wishes of traditional owners and users. On this basis, we propose a broad definition of conservation professionals as 'all those whose work diagnoses conservation needs and implements appropriate conservation action, both making use of and generating knowledge, evidence and policy'. This definition can apply to all kinds of conservation professionals, while recognizing that Indigenous and community professional frameworks have their own identities. These may overlap to varying extents 


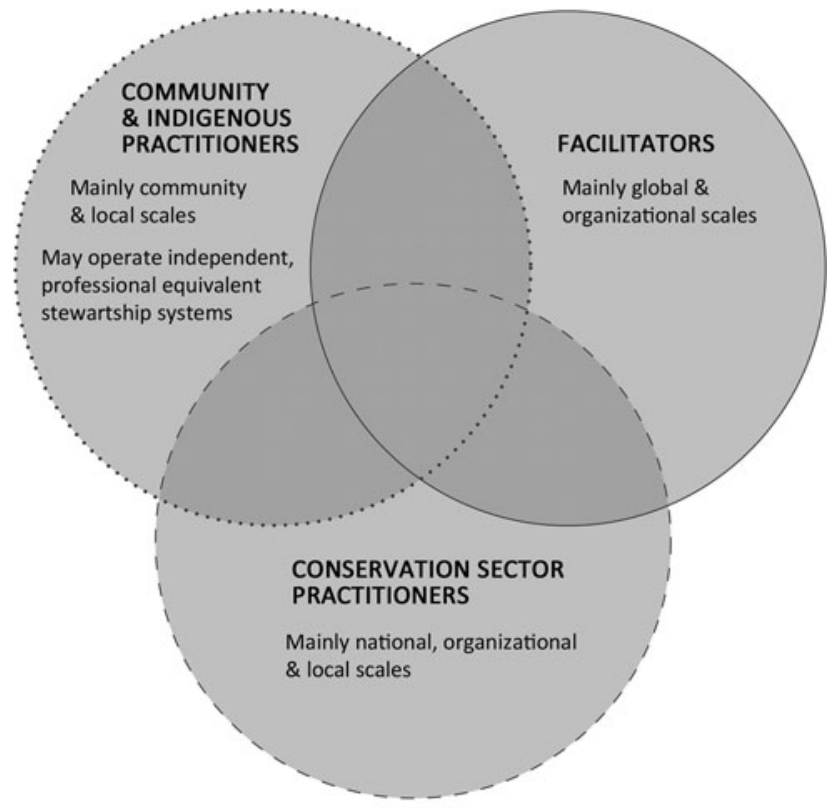

\section{RECOMMENDATIONS}

(for joint implementation in areas of overlap)

1. Secure wider recognition of the conservation profession \& sector

2. Increase the availability \& accessibility of knowledge

3. Improve the quality, relevance \& availability of training \& learning

4. Establish an ethical framework for all conservation professionals

5. Build wider \& more inclusive networks of professionals

6. Improve organizational performance, employment \& working conditions

7. Explore options for forming a professional body or network to advance professionalization

FIG. 1 Visualization of how conservation should be professionalized. The three intersecting groups that comprise the conservation sector operate at different scales (global, national, community, local, organizational). Based on our definition, the work of all conservation professionals should encompass the shaded area where these groups overlap, and should seek to expand these areas of overlap, within which our seven recommendations (Table 1) should be implemented.

with more globally established professional frameworks but should not be subsumed into them.

\section{Recommendations}

Table 1 outlines seven broad recommendations that we identify for advancing the professional attributes of the conservation sector and for creating a distinct, inclusive profession without constraining the benefits that come from the diverse and multidisciplinary nature of the sector. Specific measures for pursuing these recommendations will need to reflect the geographical, cultural and institutional contexts in which they are implemented. Figure 1 summarizes these recommendations in the context of the framework for conservation professionals set out here.

This review was stimulated by the need for a better understanding of the terms 'professional' and 'professionalization' in the context of conservation. Although both terms are widely used, this is the first such review that we are aware of. Our intention here is to encourage further studies and debate, and more importantly to encourage development of a distinctive and inclusive profession that can meet the challenges of conservation in the 21st century.

Acknowledgements We thank the International Academy for Nature Conservation of the German Federal Agency for Nature Conservation for supporting the workshop in 2017, where many of the ideas presented here first took shape. We acknowledge the contributions of organizers and participants at the 2019 London Capacity Building for Conservation Conference, at related conferences in Colombia (2013), Kenya (2015) and India (2017), at the III Latin American and Caribbean Congress of Protected Areas (2019) and the 9th World Ranger Congress (2019). We thank two anonymous reviewers and the Editor for their comments and suggestions, which helped improve and clarify this review.

Author contributions Conception, writing: MRA; Fig. 1: NRO, MRA; literature search: ES; revision: all authors.

\section{Conflicts of interest None.}

Ethical standards This review abided by the Oryx guidelines on ethical standards and did not involve human or animal test subjects or the collection of specimens.

\section{References}

Аввотт, A.D. (1988) The System of Professions: An Essay on the Division of Expert Labor. University of Chicago Press, Chicago, USA.

Adams, W.M. \& Sandbrook, C. (2013) Conservation, evidence and policy. Oryx, 47, 329-335.

Adams, W.M., Balmford, A., McNeely, J.A., Maunder, M., Milner-Gulland, E.J., Racey, P. \& Robinson, J.G. (2001) Code of Conduct for Researchers Contributing Articles to Oryx-The International Journal of Conservation. Oryx, 35, 99-100.

Appleton, M.R. (2016) A Global Register of Competences for Protected Area Practitioners. IUCN, Gland, Switzerland.

Appleton, M.R., Ioniță, A. \& Stanciu, E. (2017) Pathways to Professionalisation: Developing Individual and Organisational Capacities for Protected Area Management. Lessons From Eastern Europe. Bundesamt für Naturschutz, Bonn, Germany.

Banks, N., Hulme, D. \& Edwards, M. (2015) NGOs, states and donors revisited: still too close for comfort? World Development, 66, 707-718.

Belecky, M., Singh, R. \& Moreto, W. (2019) Life on the Frontline 2019: A Global Survey of the Working Conditions of Rangers. WWF, Gland, Switzerland.

Bennett, N.J., Teh, L., Ota, Y., Christie, P., Ayers, A., Day, J.C. et al. (2017) An appeal for a code of conduct for marine conservation. Marine Policy, 81, 411-418.

B FN (Bundesamt FÜr Naturschutz) (2017) Building Institutional Capacity in Government Conservation and Protected Area Organisations: A Workshop to Explore Options and Identify Directions. IUCN-World Commission on Protected Areas, Gland, Switzerland and Bundesamt für Naturschutz, Bonn, Germany. bfn.de/fileadmin/BfN/ina/Dokumente/Tagungsdoku/2017/Vilm_ organisational_workshop_jan_2017_Final_Report_barrierefrei.pdf [accessed 4 October 2021]. 
Blanchard, L., Sandbrook, C.G., Fisher, J.A. \& Vira, B. (2018) Investigating the consistency of a pro-market perspective amongst conservationists. In The Anthropology of Conservation NGOs: Rethinking the Boundaries (eds P.B. Larsen \& D. Brockington), pp. 151-18o. Springer International Publishing, Cham, Switzerland.

Bonine, K., Reid, J. \& D Alzen, R. (2003) Training and education for tropical conservation. Conservation Biology, 17, 1209-1218.

Brock, D.M., Leblebici, H. \& Muzio, D. (2014) Understanding professionals and their workplaces: the mission of the Journal of Professions and Organization. Journal of Professions and Organization, 1, 1-15.

Bruyere, B., Bynum, N., Copsey, J., Porzecanski, A. \& Sterling, E. (2020) Conservation Leadership Capacity Building: A Landscape Study and Recommendations. American Museum of Natural History, New York, USA. amnh.org/research/center-forbiodiversity-conservation/resources-and-publications/ conservation-action-and-planning/conservation-leadershipcapacity-building-a-landscape-study [accessed 24 February 2021].

Caвayan, I.G. (2019) New International Organization for Standardization Certification Inspires National Parks Development Committee to DO More. archive.journal.com.ph/editorial/opinion/ new-international-organization-standardization-certificationinspires-national [accessed 9 May 2020].

Cambridge University Press (2020) Cambridge Dictionary. Cambridge University Press, Cambridge, UK. dictionary. cambridge.org/dictionary/english [accessed 10 May 2020].

Castañeda Camey, I., Sabater, L., Owren, C. \& Boyer, A.E. (2020) Gender-Based Violence and Environment Linkages: The Violence of Inequality. IUCN, Gland, Switzerland.

CBD (Convention on Biological Diversity) (2010) Decision Adopted by the Conference of the Parties to the Convention on Biological Diversity at its Tenth Meeting. X/42. The Tkarihwaié:ri Code of Ethical Conduct to Ensure Respect for the Cultural and Intellectual Heritage of Indigenous and Local Communities. cbd.int/ doc/decisions/COP-10/cop-10-dec-42-en.doc [accessed November 2021].

Chiocchio, F. \& Richer, M.-C. (2015) From multi-professional to trans-professional healthcare teams: the critical role of innovation projects. In Challenges and Opportunities in Health Care Management (eds S. Gurtner \& K. Soyez), pp. 161-169. Springer International Publishing, Cham, Switzerland.

CIEEM (2019) Code of Professional Conduct. Chartered Institute of Ecology and Environmental Management, Winchester, UK.

CAPACITY FOR Conservation (2021) capacityforconservation.org [accessed 4 October 2021].

Conservation Assured (2018) CATS Manual Version 2 June 2018. Conservation Assured, Singapore.

Conservation Evidence (2021) Conservation Evidence: Providing Evidence to Improve Practice. Conservation Evidence, Cambridge, UK. conservationevidence.com [accessed 24 February 2021].

Corporate Finance Institute (2020) What is a Professional? corporatefinanceinstitute.com/resources/knowledge/other/ professional [accessed 20 October 2020].

Dolomiti Bellunesi National Park (2020) ISO 9001-14001 Integrated Certification-EMAS II Registration. dolomitipark.it/en/ page.php? $\mathrm{id}=618$ [accessed 9 May 2020].

Dudley, N. \& Stolton, S. (2020) Leaving Space for Nature: The Critical Role of Area-Based Conservation. Routledge, Abingdon, UK.

Evetts, J. (2006) Introduction. Current Sociology, 54, 515-531.

Fabian, Y., Bollmann, K., Brang, P., Heiri, C., Olschewski, R., Rigling, A., Stofer, S. \& Holderegger, R. (2019) How to close the science-practice gap in nature conservation? Information sources used by practitioners. Biological Conservation, 235, 93-101.

Fournier, A.M.B. \& Bond, A.L. (2015) Volunteer field technicians are bad for wildlife ecology. Wildlife Society Bulletin, 39, 819-821.
Francis, R.A. \& Goodman, M.K. (2010) Post-normal science and the art of nature conservation. Journal for Nature Conservation, $18,89-105$.

Fuller, J.B. \& Raman, M. (2017) Dismissed by Degrees: How Degree Inflation Is Undermining U.S. Competitiveness and Hurting America's Middle Class. Accenture, Grads of Life and Harvard Business School, Boston, USA.

GANTHERU, W. (2020) It's time for environmental studies to own up to erasing black people. Vice, 11 June 2020. vice.com/en_us/article/ 889qxx/its-time-for-environmental-studies-to-own-up-to-erasingblack-people [accessed 18 June 2020].

Giehl, E.L.H., Moretti, M., Walsh, J.C., Batalha, M.A. \& Cook, C.N. (2017) Scientific evidence and potential barriers in the management of Brazilian protected areas. PLOS ONE, 12, eo169917.

Gossa, C., Fisher, M. \& Milner-Gulland, E.J. (2015) The research-implementation gap: how practitioners and researchers from developing countries perceive the role of peer-reviewed literature in conservation science. Oryx, 49, 80-87.

HANCE, J. (2016) How big donors and corporations shape conservation goals. Mongabay, 3 May 2016. news.mongabay.com/2016/05/bigdonors-corporations-shape-conservation-goals [accessed 9 May 2020].

Hance, J. (2017) A rich person's profession? Young conservationists struggle to make it. Mongabay, 16 August 2017. news.mongabay. com/2017/o8/a-rich-persons-profession-young-conservationistsstruggle-to-make-it [accessed 9 May 2020].

Handy, G. (2019) Antigua: sprawling 'Chinese colony' plan across marine reserve ignites opposition. The Guardian, 20 June 2019. theguardian.com/world/2019/jun/20/antigua-yida-project-chinesecolony-controversy [accessed 18 June 2020].

Hockings, M., Adams, W., Brooks, T.M., Dudley, N., Jonas, H., Lotter, W. et al. (2013) A draft code of practice for research and monitoring in protected areas. PARKS, 19, 85-94.

Holmes, G. (2011) Conservation's friends in high places: neoliberalism, networks, and the transnational conservation elite. Global Environmental Politics, 11, 1-21.

Holmes, G. (2015) Philanthrocapitalism, biodiversity conservation and development. In New Philanthropy and Social Justice: Debating the Conceptual and Policy Discourse (ed. B. Morvaridi), 81-10o. Policy Press, Bristol, UK.

Humble, D. (2019) Recasting professionalisation: understanding self-legitimating professionalisation as a precursor to neoliberal professionalisation. Geoforum: Journal of Physical, Human, and Regional Geosciences, 106, 135-143.

Hurd, R.W. \& Lakhani, T. (2008) Unions, Associations and Twenty-First Century Professionals. UNI Global Union, Nyon, Switzerland.

International Labour Office (2008) International Standard Classification of Occupations ISCO-o8. International Labour Office, Geneva, Switzerland.

International Ranger Federation (2021) Ranger Code of Conduct. Version 1.o. International Ranger Federation, Victoria, Australia.

iUCN Papaco (Program on African Protected Areas \& Conservation) (2021) MOOCs on Conservation \& PAs. papaco.org/moocs [accessed 1 March 2021].

iUCN \& WCPA (World Commission on Protected Areas) (2017) IUCN Green List of Protected and Conserved Areas: Standard, Version 1.1. IUCN, Gland, Switzerland.

Jeanson, A.L., Soroye, P., Kadykalo, A.N., Ward, T.D., Paquette, E., Abrams, A.E.I. et al. (2020) Twenty actions for a 'good Anthropocene'-perspectives from early-career conservation professionals. Environmental Reviews, 28, 99-108.

Jones, M.S. \& Solomon, J. (2019) Challenges and supports for women conservation leaders. Conservation Science and Practice, 1, e36. 
KIIK, L. (2019) Conservationland: toward the anthropology of professionals in global nature conservation. Critique of Anthropology, 39, 391-419.

Klas, A., Zinkiewicz, L., Zhou, J. \& Clarke, E.J.R. (2018) 'Not all environmentalists are like that': unpacking the negative and positive beliefs and perceptions of environmentalists. Environmental Communication, 13, 879-893.

LanG, S. (2013) NGOs, Civil Society, and the Public Sphere. Cambridge University Press, Cambridge, UK.

Larsen, P. (2018) The good, the ugly and the dirty Harry's of conservation: rethinking the anthropology of conservation NGOs. Conservation and Society, 14, 21-33.

Lowenthal, D. (1999) Heritage stewardship and the amateur tradition. APT Bulletin, 30, 7-9.

Lucas, J., Gora, E. \& Alonso, A. (2017) A view of the global conservation job market and how to succeed in it. Conservation Biology, 31, 1223-1231.

Maggs, G., Appleton, M.R., Long, B. \& Young, R.P. (2021) A Global Register of Competences for Threatened Species Recovery Practitioners: A Comprehensive List of Skills, Knowledge and Personal Attributes Required by Practitioners Working within Threatened Species Recovery. IUCN, Gland, Switzerland.

Maliasili (2020) maliasili.org [accessed 4 October 2021].

Mbaria, J. \& Ogada, M. (2017) The Big Conservation Lie: The Untold Story of Wildlife Conservation in Kenya. Lens \& Pens, Seattle, USA.

Mieg, H.A. (2008) Professionalisation and professional identities of environmental experts: the case of Switzerland. Environmental Sciences, 5, 41-51.

Mieg, H.A. (2009) Two factors of expertise? Excellence and professionalism of environmental experts. High Ability Studies, 20, 91-115.

Muir, M.J. \& Schwartz, M.W. (2009) Academic research training for a nonacademic workplace: a case study of graduate student alumni who work in conservation. Conservation Biology, 23, 1357-1368.

Munro, N. (1992) An international society of protected area managers and professionals. The George Wright Forum, 9, 65-70.

NADASDy, P. (2003) Hunters and Bureaucrats: Power, Knowledge, and Aboriginal-State Relations in the Southwest Yukon. UBC Press, Vancouver, Canada.

O'Connell, M. \& White, R. (2017) Academics can also be culprits of evidence complacency. Nature Ecology \& Evolution, 1, 1215-1216.

Painter, M. \& Kretser, H.E. (2012) Contextual awareness in long-term partnerships builds adaptive capacity for conservation. Human Dimensions of Wildlife, 17, 357-366.

Papworth, S., Thomas, R.L. \& Turvey, S.T. (2019) Increased dispositional optimism in conservation professionals. Biodiversity and Conservation, 28, 401-414.

Paterson, B. (2006) Ethics for wildlife conservation: overcoming the human-nature dualism. BioScience, 56, 144-150.
Reihlen, M. \& Mone, M. (2012) Professional service firms, knowledge-based competition, and the heterarchical organization form. In Handbook of Research on Entrepreneurship in Professional Services (eds M. Reihlen \& A. Werr), pp. 107-126. Edward Elgar Publishing, Cheltenham, UK.

SAKs, M. (2012) Defining a profession: the role of knowledge and expertise. Professions and Professionalism, 2, 1-10.

Sandbrook, C., Fisher, J.A., Holmes, G., Luque-Lora, R. \& KeAne, A. (2019) The global conservation movement is diverse but not divided. Nature Sustainability, 2, 316-323.

Singh, R., Galliers, C., Appleton, M., Hoffmann, M., Long, B., CARy-Elwes, J. et al. (2021) The vital role of rangers in conservation. Parks Stewardship Forum, 37, 128-136.

Smith, R., Biggs, D., John, F., Sas-Rolfes, M. \& Barrington, R. (2015) Elephant conservation and corruption beyond the ivory trade. Conservation Biology, 29, 953-956.

Taff, B., Jones, M., Bruyere, B., Newman, P., Barborak, J., Manfredo, M. \& Finchum, R. (2015) The role of universities in protected area management: considerations for the future. The George Wright Forum, 32, 308-316.

Tauli-Corpuz, V., Alcorn, J., Molnar, A., Healy, C. \& Barrow, E. (2020) Cornered by PAs: adopting rights-based approaches to enable cost-effective conservation and climate action. World Development, 130, 104923.

UNODC (2019) Scaling Back Corruption: A Guide to Addressing Corruption for Wildlife Management Authorities. United Nations Office on Drugs and Crime, Vienna, Austria.

Walsh, J.C., Dicks, L.V. \& Sutherland, W.J. (2015) The effect of scientific evidence on conservation practitioners' management decisions. Conservation Biology, 29, 88-98.

WARREN, T. \& BAKER, K.J.M. (2019) WWF has suspended support for rangers at a major nature reserve after a suspicious death. Buzzfeed News, 11 December 2019. buzzfeednews.com/article/tomwarren/ wwf-has-suspended-support-for-rangers-at-africas-largest [accessed 9 May 2020].

Webley, S. \& Werner, A. (2008) Corporate codes of ethics: necessary but not sufficient. Business Ethics: A European Review, 17, 405-415.

Well Grounded (2021) well-grounded.org [accessed 4 October 2021].

Whitten, T., Holmes, D. \& MacKinnon, K. (2001) Conservation biology: a displacement behavior for academia? Conservation Biology, 15, 1-3.

Wiomsa (Western Indian Ocean Marine Science Association) (2020) Annual Report 2019. Western Indian Ocean Marine Science Association, Zanzibar, Tanzania. wiomsa.org/wpcontent/uploads/2020/10/Wiomsa-AR-2019-final-LR-20-OCT.pdf [accessed 2020]

WWF (2009) WWF Code of Ethics. World Wildlife Fund, Gland, Switzerland. d2ouvy59podg6k.cloudfront.net/downloads/wwf_ code_of_ethics.pdf [accessed 9 May 2020]. 